\title{
TGF- $\beta 1$ Expression by Proliferated Keratinocytes in the Skin of E-Irradiated Mice
}

\author{
A-Ran Yoon', Do Nyun Kim', Min Koo Seo', Sang Taek Oh', Jung Seon Seo', Se Mo Jun', \\ Jung-Ho Cha², Seungdeok Lee ${ }^{3}$ and Suk Kyeong Lee * \\ ${ }^{1}$ Department of Medical Lifescience, ${ }^{2}$ Department of Anatomy, College of Medicine, The Catholic University of Korea, Seoul 137-701, Korea \\ ${ }^{3}$ Department of Oriental Medicine, The Graduate School of Dongguk University, Gyeongiu 780-714, Korea
}

Received November 16, 2011 /Revised November 25, 2011 /Accepted November 27, 2011

\begin{abstract}
In this study, we established a radiodermatitis animal model and investigated the change in immune cell proportions in the secondary lymphoid organs. The cells responsible for the increased transforming growth factor- $\beta 1$ (TGF-B1) and interleukin-10 (IL-10) production in the lesions following irradiation were also investigated. The radiodermatitis model was constructed by locally exposing the posterior dorsal region of hairless-1 (HR-1) mice to 10 Gy electron (E)-ray/day for six consecutive days. The change in immune cell proportions was analyzed by FACS. Immunohistochemistry was carried out to detect the expression of cytokines and cell-specific markers in the skin. The proportions of antigen-presenting cells, $\mathrm{T}$ cells, and $\mathrm{B}$ cells in the lymph nodes and spleen were affected by E-irradiation. After irradiation, TGF- $\beta 1$ and IL-17 were co-localized in the papillary region of the dermis with keratin-14 (K-14)-positive cells rather than with regulatory $\mathrm{T}$ cells (Treg). IL-10 was not co-stained with Treg, T helper 17 (Th17) cells, dendritic cells, or macrophages. Our data indicate that TGF- $\beta 1$ is over-expressed mainly by proliferated keratinocytes in the lesions of a radiodermatitis animal model.
\end{abstract}

Key words : Transforming growth factor- $\beta 1$, keratinocyte, radiodermatitis, interlukin-10, regulatory $\mathrm{T}$ cell

\section{Introduction}

Radiotherapy has been used for a long while in cancer treatment. In lesions caused by radiation-induced dermatitis, increased expression of transforming growth factor- $\beta 1$ (TGF$\beta 1$ ) has been reported [18]. Not only TGF- $\beta 1$ functions as a master switch for radiation-induced fibrosis, it also affects differentiation, survival, and proliferation of immune cells by stimulating TGF- $\beta 1$ receptor on the cells. TGF- $\beta 1$, together with interlukin-6 (IL-6), regulates T cell differentiation to $\mathrm{T}$ helper 17 (Th17) cells [11]. Th17 cells express interlukin-17 (IL-17) and are associated with autoimmune diseases as well as chronic inflammatory diseases [20,29]. TGF- $\beta 1$ also plays an important role with IL-10 in differentiation and function of peripheral regulatory $\mathrm{T}$ (Treg) cells which express forkhead box P3 (Foxp3) transcription factor. In contrast to Th17, Treg suppresses activation of the immune system. In addition, TGF- $\beta 1$ is a potent epithelial growth inhibitor [31] which can affect differentiation of keratinocyte in the epi-

*Corresponding author

Tel : +82-2-2258-7480, Fax : +82-2-535-7481

E-mail : sukklee@catholic.ac.kr dermis [5], and is an important regulator in the maintenance of tissue homeostasis $[14,33]$. In this study, we established a radiodermatitis animal model by irradiating hairless mice. Increased expression of TGF- $\beta 1$ and IL-10 as well as increased Treg population were observed in the skin after irradiation. We then analyzed the type of cells from which TGF- 31 and IL-10 were expressed and relationship between these cytokines as well as Treg.

\section{Materials and Methods}

\section{Animals and electron (E)-Irradiation}

Five week old hairless-1 (HR-1) mice were purchased from Hoshino Laboratory Animal Center (Yashio, Japan) and adapted for 1 week under conventional conditions prior to experiments. For irradiation, mice were anesthetized by injecting $0.1 \mathrm{ml}$ mixture (5:1 ratio) of Ketamine (Yuhan, Seoul, Korea) and Rompun (Bayer Korea, Gyeonggi-do, Korea). All mice were taped down to an acrylic plate and irradiated using Clinac 2100 C-G accelerator (Varian, Salt City, UT). The posterior dorsal regions of HR-1 mice were exposed to an electron (E)-ray at a dose rate of $4.1 \mathrm{~Gy} / \mathrm{min}$, 
10 Gy/day for 6 consecutive days. The spleen, inguinal lymph nodes, and the bone marrow were protected using lead shields from the E-irradiation. Sham-irradiated control mice were also anesthetized and taped down similar to the irradiated mice without irradiation. All procedures of animal research were performed in accordance with the Guide for the Care and Use of Laboratory Animals provided by the IACUC (Institutional Animal Care and Use Committee) in College of Medicine, The Catholic University of Korea.

\section{Flow cytometry analysis}

To isolate cells from the spleen and inguinal lymph nodes, we followed the previously reported methods [17]. Immunophenotyping of splenocytes and inguinal lymphocytes was carried out using a FACS Calibur flow cytometer (BD Biosciences, San Jose, CA, USA). Peridinin chlorophyll A protein complex (PerCP)-conjugated anti-mouse CD4 (eBioscience, San Diego, CA, USA), phycoerythrin (PE)-conjugated anti-mouse CD8 (BD Biosciences), fluorescein isothiocyanate (FITC)-conjugated anti-mouse FoxP3 (eBioscience), allophycocyanin (APC)-conjugated anti-mouse CD25 (eBioscience), APC-conjugated anti-mouse CD11b (BD Biosciences), PE-conjugated anti-mouse CD11c (BD Biosciences), and FITC-conjugated anti-mouse B220 (BD Biosciences) were used. To assess non-specific binding, PE-conjugated isotype antibody was obtained from BD Biosciences. Cell surface staining was carried out with the fluorescent-labeled antibodies at $4^{\circ} \mathrm{C}$ for $20 \mathrm{~min}$. Intracellular staining of the Fox $3^{+}$cells was carried out following cell surface staining with APC-conjugated anti-mouse CD25. The results were analyzed using Cell Quest Software (BD Biosciences).

\section{Immunohistochemical analysis}

Staining was performed on frozen-embedded sections of mouse dorsal skin. Samples were cut into $6 \mu \mathrm{m}$ thick sections and mounted onto silane-coated slides (Marienfeld, Lauda-Königshofen, Germany). The samples were then fixed in a ice-cold mixture of methanol and acetone (1:1) for 15 min and blocked in 20\% normal goat serum for $90 \mathrm{~min}$. Primary antibodies used in this study were affinity purified rat anti-mouse Foxp3 (eBioscience), rabbit anti-mouse TGF- $\beta$ 1 (Santa Cruz Biotechnology, Inc., Santa Cruz, CA, USA), rat anti-mouse IL-6, goat anti-mouse IL-17 (R\&D Systems, Minneapolis, MN, USA), rat anti-mouse keratin-14 (COVANCE, Emeryville, CA, USA), PE-conjugated hamster anti-mouse CD11c, PE-conjugated rat anti-mouse CD11b, and biotin-conjugated rat anti-mouse IL-10 (BD Biosciences). Secondary antibodies used to detect the primary antibodies were anti-rat Cy3 (Santa Cruz Biotechnology, Inc.), anti-rabbit FITC (Santa Cruz Biotechnology, Inc.), anti-rat FITC (Santa Cruz Biotechnology, Inc.), and anti-goat Cy3 (Santa Cruz Biotechnology, Inc.). To detect CD11b and CD11c, secondary antibodies were not needed because the primary antibodies were PE-conjugated. Expression of IL-10 in the skin was detected using FITC-conjugated streptavidin (Santa Cruz Biotechnology, Inc.). Before observe the staining, nuclear DNA was stained with the DAPI reagent (Invitrogen, Eagene, OR, USA).

\section{Statistical analysis}

Body weights of the mice during the experimental periods were analyzed by one-way repeated-measure analysis of variance (ANOVA). Significant difference between the sham-irradiated and the E-irradiated group along the period of experiments was determined by the Bonferroni method. Paired t-tests were performed to compare initial and follow-up body weights for each grou lsk updp. The changes of the immune cell proportion were analyzed by one-way ANOVA followed by Bonferroni's post hoc analysis.

The statistical calculations were performed with Stata/SE software (version 9.0; Stata Corp, College Station, TX, USA.). $P$-values less than 0.05 were considered statistically significant. All results are expressed as the mean \pm standard error (SEM).

\section{Results}

\section{Establishment of a radiodermatitis mouse model}

Skin change of the E-irradiated mice was first observed on the day 13 and observed at least up to the $24^{\text {th }}$ day after the first E-irradiation (Fig. 1A). On the day 15 following E-irradiation, dry desquamation had increased and inflammation was observed on the back skin of some mice. By day 22, inflammation on the back skin and bleeding from the tail was observed in some of the E-irradiated mice.

The repeated-measure ANOVA revealed significant differences in body weights $(p<0.001)$ between the sham- and the E-irradiated groups. Body weights were significantly lowered in the E-irradiated group than the sham-irradiated group between the $6^{\text {th }}$ and the $23^{\text {rd }}$ day (Fig. 1B). No conventional pathogenic infection of the HR-1 mice was observed 

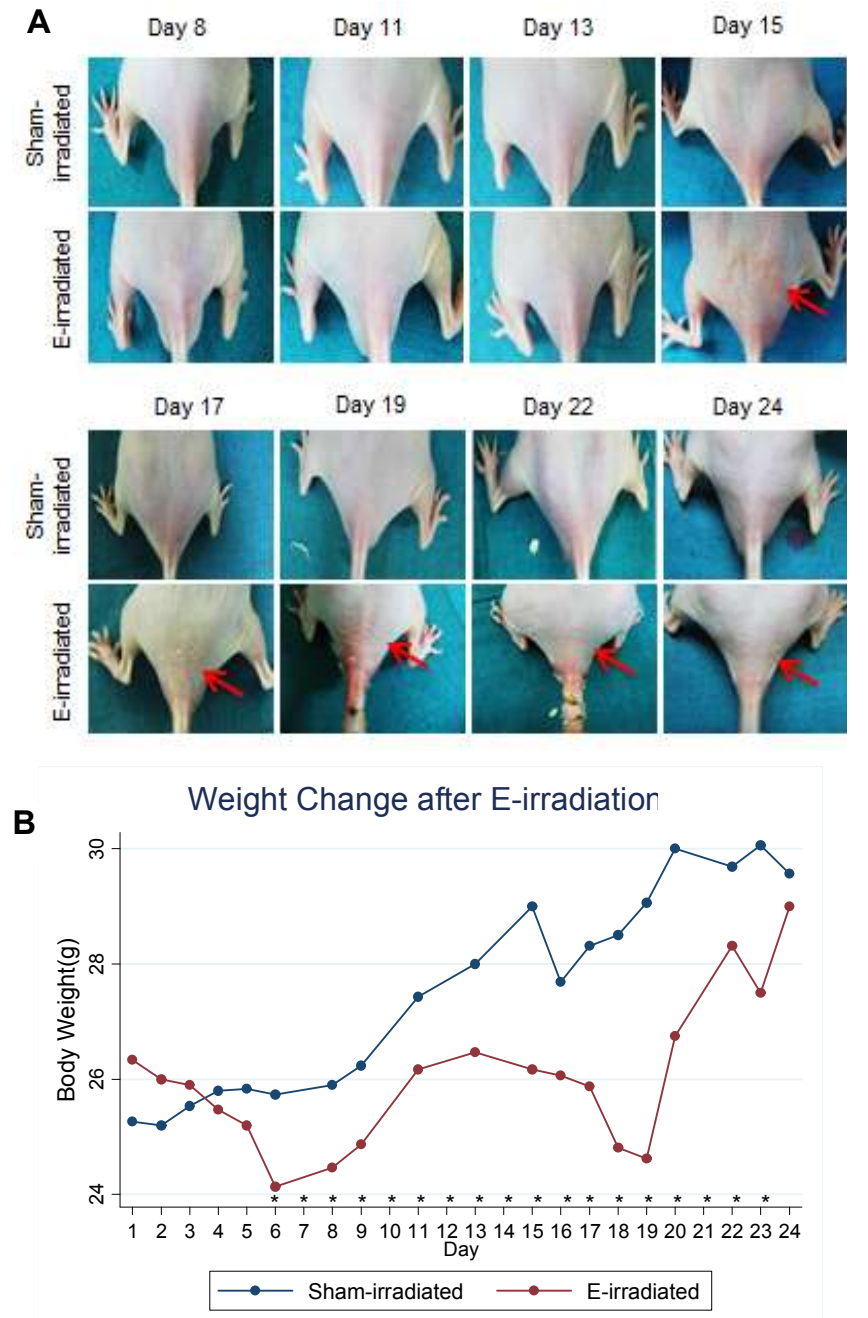

Fig. 1. Establishment of a radiodermatitis mouse model. HR-1 mice were E-irradiated on the dorsal buttock region with $10 \mathrm{~Gy} /$ day for six consecutive days. (A) Surface macrophotography of the radiodermatitis model. The arrows indicate the lesions showing severe inflammation. (B) Change in body weight of HR-1 mice after E-irradiation. Data are represented as mean (1-15 days: $\mathrm{n}=15$ for both groups, 16-24 days: $\mathrm{n}=8$ for both groups).*: $p<0.05$

in serological, culture, and parasitological tests during the experiment period.

Alteration of immune cell proportions in the spleen and lymph nodes of the E-irradiated mice

To examine the alteration of immune cell proportions in the spleen and lymph nodes after E-irradiation, a FACS analysis was carried out for the cells (Fig. 2). CD11b ${ }^{+}$cells in lymph nodes increased after E-irradiation compared to the control mice after both 15 and 24 days. After irradiation, $\mathrm{CD}_{11 \mathrm{c}^{+}}$cells decreased slightly in the spleen while increased
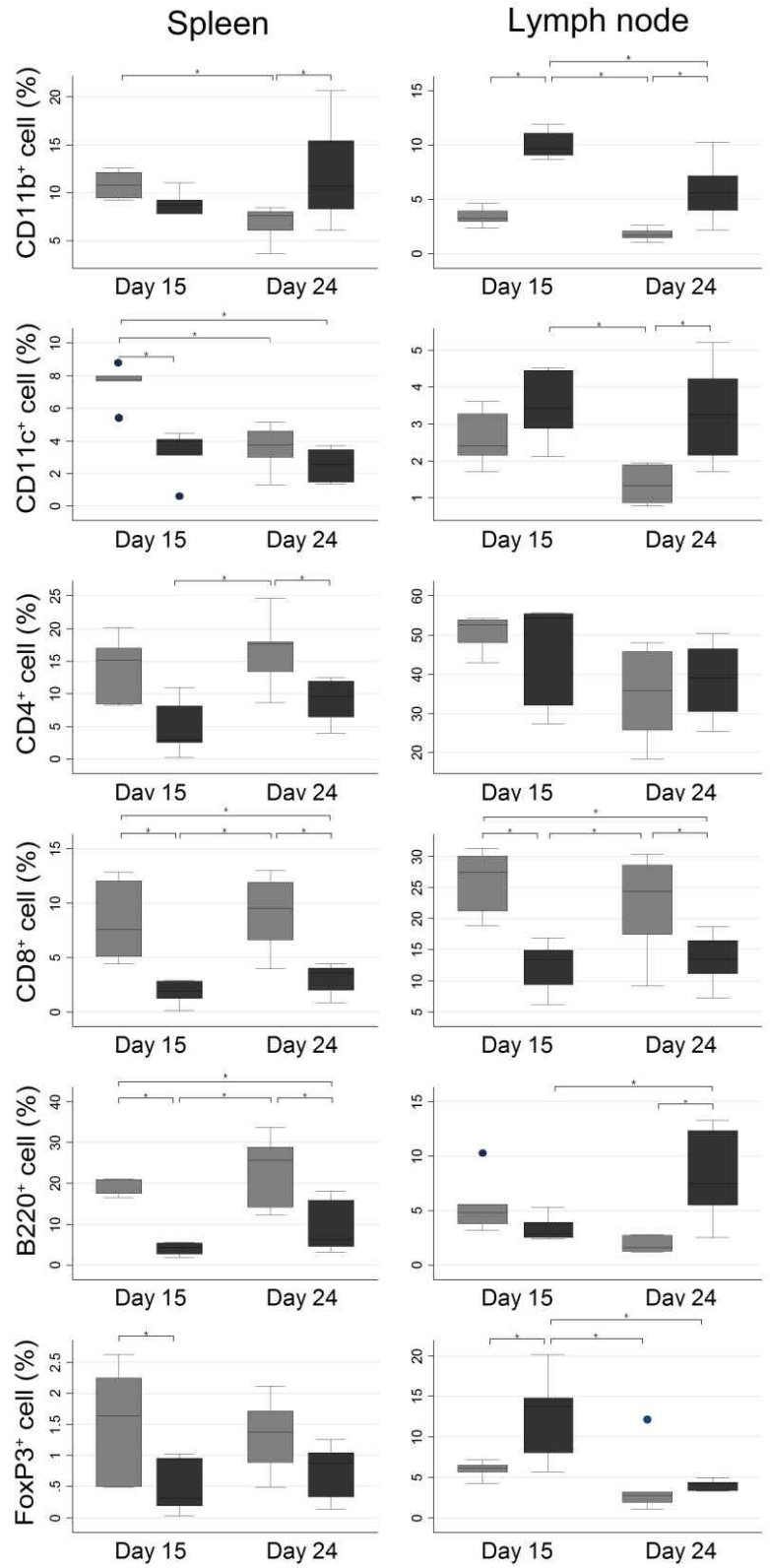

Time after E-irradiation(day) Time after E-irradiation(day)

Fig. 2. Relative proportion of immune cell subpopulations analyzed by FACS in lymph nodes and the spleen after E-irradiation. Data are represented as mean \pm SE. Gray bar: sham-irradiated mice (Day 15: $n=7$, Day 24: $n=8$ ), black bar: E-irradiated mice (Day 15: $n=7$, Day 24: $n=8$ ). *: $p<0.05$

in lymph nodes. The proportion of $\mathrm{CD}^{+}$helper $\mathrm{T}$ cells exhibited a sharp decrease in the spleen after 24 days of E-irradiation. The proportion of $\mathrm{CD}^{+}$cells decreased approximately 4-fold in the spleen and 2-fold in lymph nodes after E-irradiation. B220 $0^{+}$B cells in the spleen decreased after E-irradiation, while B cells in lymph nodes increased than 
the sham-irradiated group after 24 days of E-irradiation.

Approximately $1-1.5 \%$ of the spleen cells and $4-6 \%$ of lymph node cells were $\mathrm{FoxP}^{+}$cells in the sham-irradiated mice. Fifteen days after E-irradiation, there was a 3-fold decrease of FoxP3 ${ }^{+}$cells in the spleen and a 2.5-fold increase in lymph nodes. Twenty four days after the E-irradiation, the changed proportion of $\mathrm{FoxP}^{+}$cells in the spleen and lymph nodes had returned to a similar level with the sham-irradiated mice. Interestingly, all the cells checked by FACS showed decreased percentages in the spleen after E-irradiation, but the proportions of the cells in lymph nodes were variably affected by E-irradiation depending on the cell types.

Relative location of TGF- $\beta 1, \quad \| \mathrm{L}-10$, and FoxP3 expression in the radiodermatitis lesions

Immunohistochemistry was carried out for the frozen section of the mouse skin on the 15 and 24 days after E-irradi- ation (Fig. 3A). Specific antibodies to FoxP3, TGF- $\beta 1$, and IL-10 were applied for the detection.

FoxP3 expression was rarely detected in the sham-irradiated skin but began to increase in the dermis following E-irradiation (Fig. 3A and 3B). After 24 days of E-irradiation, FoxP3 expression increased further than after 15 days. Sham-irradiated mouse skin showed scattered expression of TGF- $\beta 1$ in the dermis and the epidermis. A heavier TGF- $\beta 1$ staining in the epidermis was exhibited after 24 days than after 15 days following E-irradiation. IL-10 was detected mainly around the hair follicles without E-irradiation. IL-10 expression in the dermis increased on the $15^{\text {th }}$ day after E-irradiation and then decreased somewhat on the $24^{\text {th }}$ day, but still higher than in the sham-irradiated skin.

The possibility that TGF- $\beta 1$ and IL-10 were expressed by FoxP3 positive cells was examined by double staining (Fig. 3C). FoxP3 and TGF- $\beta 1$ were occasionally co-stained, but FoxP3 and IL-10 expressions were observed mostly in
A
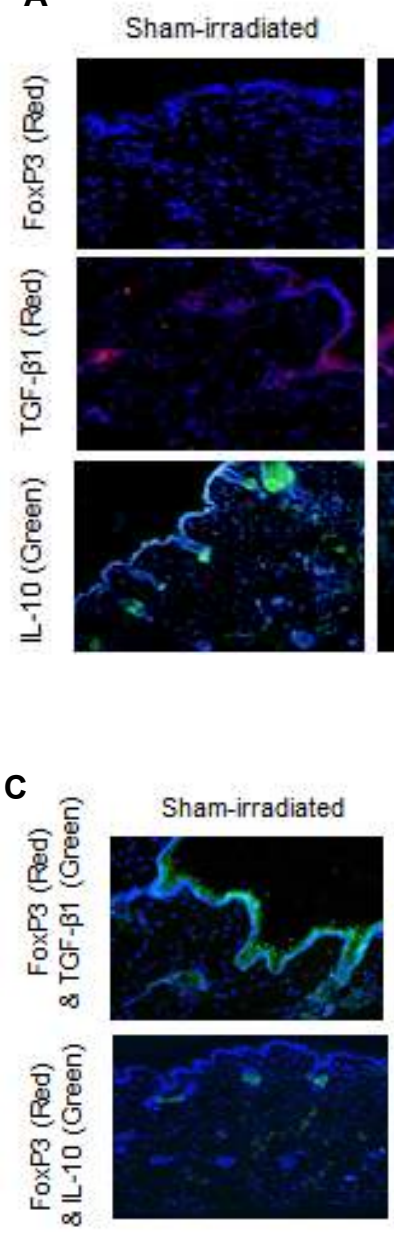
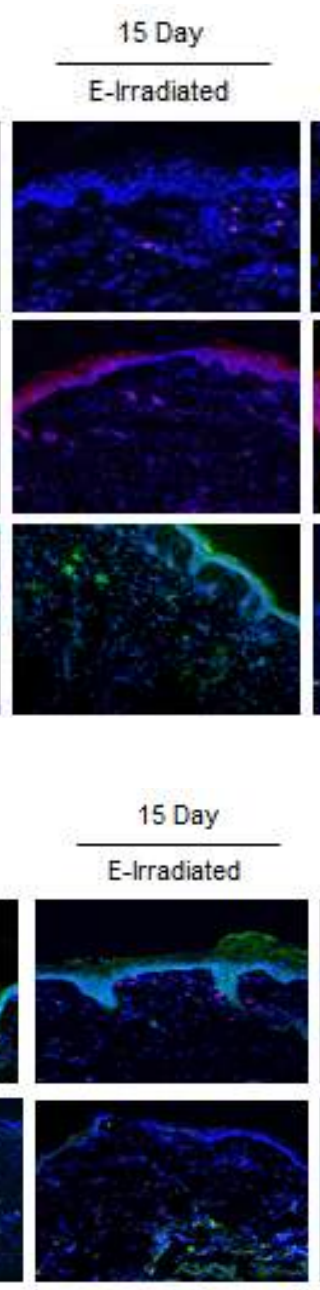
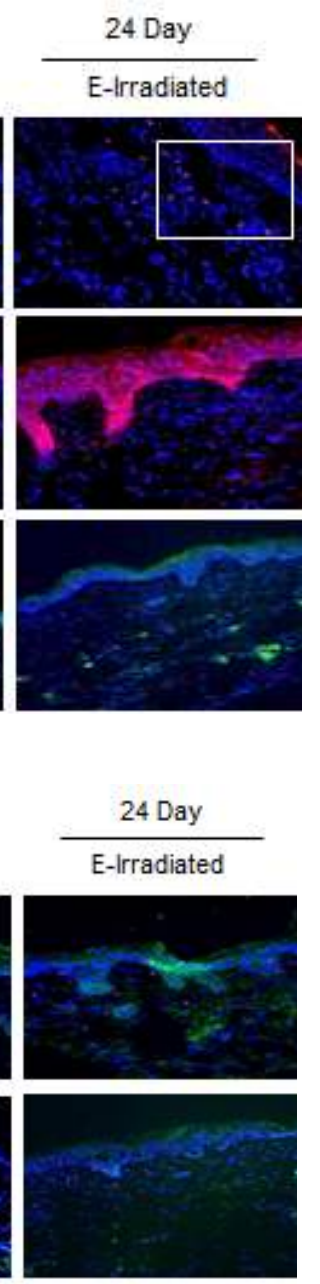

\section{B}

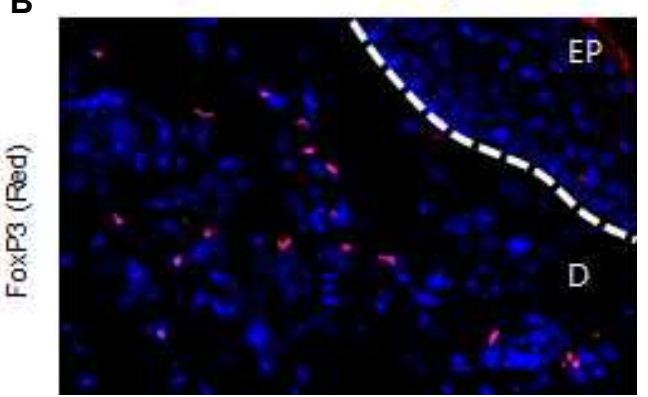

Fig. 3. Immunohistochemistry of FoxP3, TGF- 1 , and IL-10 in the skin of sham-irradiated or E-irradiated mice. (A) Expression of FoxP3 and TGF- $\beta 1$ was evaluated in the skin. Expression of IL-10 was analyzed using a biotin-conjugated primary antibody and FITC-conjugated streptavidin (x100). (B) The area in the box of the upper right panel of Fig. 3A was enlarged to show the pattern of FoxP3 staining in detail. The boundary of epidermis and dermis was indicated with the dotted line. (C) Double staining of the sham-irradiated or the E-irradiated mice skin for FoxP3 and cytokines. The co-expression of TGF- $\beta 1$ and FoxP3 or IL-10 and FoxP3 was analyzed in the skin by immunofluorescent assay. When the primary antibody was omitted for the staining to check non-specific binding of the secondary antibodies, there was no background staining (data not shown). The results are representative of three independent experiments (x100). 
different positions.

Cells expressing TGF- $\beta 1$ and $\|-10$ in the radiodermatitis lesions

As TGF- $\beta 1$ was detected at high level in the thickened epidermis following E-irradiation, we checked if TGF- $\beta 1$ is expressed by keratinocytes of the irradiated skin by double staining for TGF- 31 and K-14 (Fig. 4A). In the sham-irradiated skin, TGF- $\beta 1$ and K-14 were stained in different locations. However, TGF- $\beta 1$ was mainly co-stained with K-14 in the epidermis after 15 and 24 days following E-irradiation.

To determine whether IL-10 was expressed in the dendritic cells or macrophages of the radiodermatitis lesions,
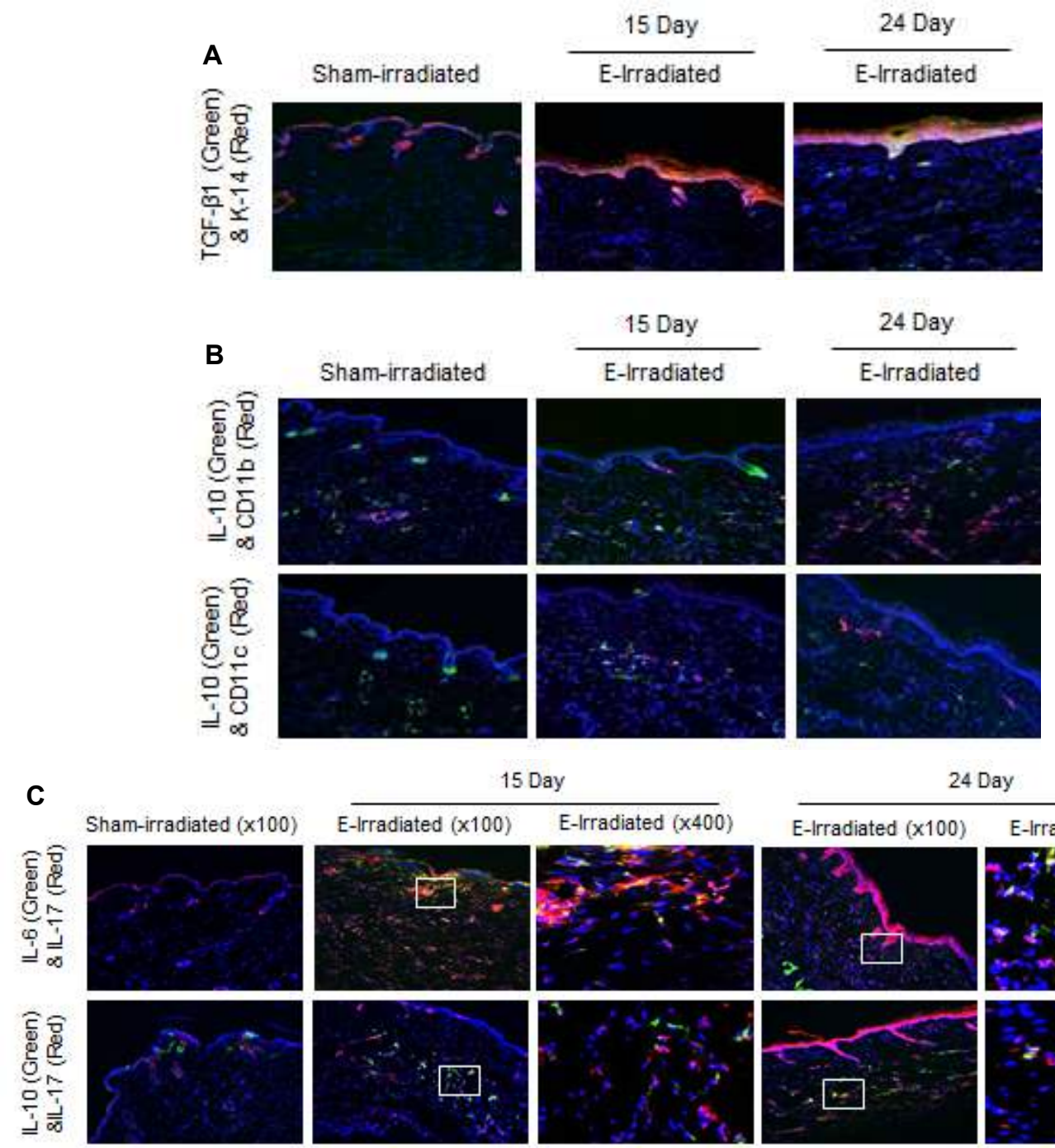

E-Irradiated $(\times 400)$

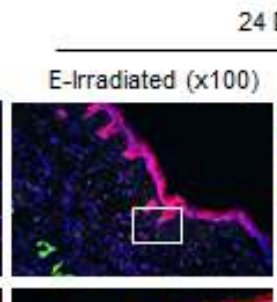

24 Day
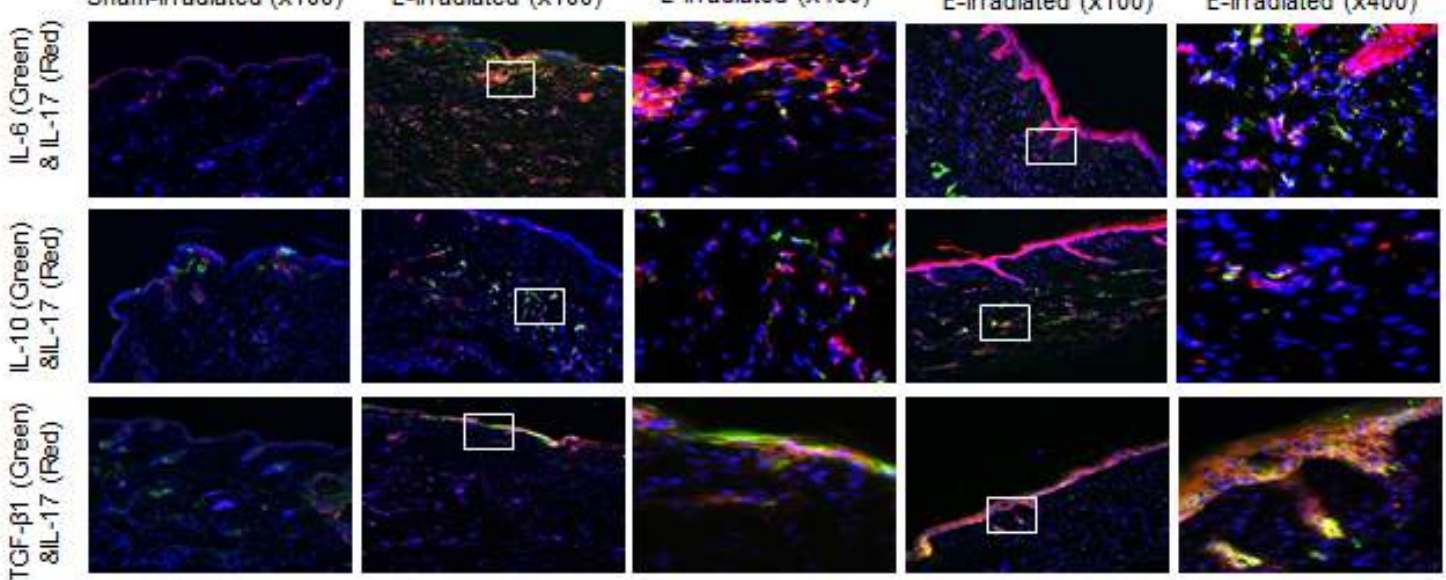

Fig. 4. Immunofluorescent assay for keratinocytes and cytokines in the skin of the sham-irradiated or the E-irradiated mice. (A) The skin section was co-incubated with antibodies for TGF- 31 and K-14 (x100). (B) Co-staining of IL-10 and CD11b, or IL-10 and CD11c in the skin of mice following E-irradiation (x100). (C) The tissue sections were incubated with goat anti-mouse IL-17 as well as with, rat anti-mouse IL-6, biotin-conjugated anti-mouse IL-10 or rabbit anti-mouse TGF- 11 antibodies. When the primary antibody was omitted for the staining to check non-specific binding of the secondary antibodies, there was no background staining (data not shown). The results are representative of three independent experiments $(\times 100,400)$. 
double staining for IL-10 and CD11b, or IL-10 and CD11c was carried out (Fig. 4B). CD11b cells were increased in the dermis on day 24 than on day 15 after E-irradiation. CD11 $\mathrm{c}^{+}$cells were also detected more frequently in the E-irradiated skin than in the sham-irradiated skin. However, $\mathrm{CD}_{11 b^{+}}$and CD11c ${ }^{+}$cells did not co-localize with IL-10.

To determine whether Th17 cells participated in the immune responses of radiodermatitis, IL-17 and IL-6 which is essential for the formation of Th17 cells were co-stained (Fig. 4C). IL-17 expression increased dramatically after E-irradiation than the sham-irradiated control. Higher IL-17 staining was observed in the dermis and the epidermis on the $24^{\text {th }}$ day than on the $15^{\text {th }}$ day after E-irradiation. IL- 6 staining increased in the skin on 15 days after E-irradiation and then slightly decreased on 24 days after E-irradiation. IL- 6 and IL-17 co-localized in a lot of cells in the dermis; however, some of them were stained in different locations. Meanwhile, the IL-10 and IL-17 stainings were only partially merged. As TGF- $\beta 1$ plays an important role in the differentiation of Th17 cells, co-expression of IL-17 and TGF- $\beta 1$ were also analyzed. IL-17 exhibited expression in the same location as TGF- $\beta 1$ in the dermis and in the epidermis. In addition, there was increased expression of both IL-17 and TGF- $\beta 1$ on the $24^{\text {th }}$ day than on the $15^{\text {th }}$ day.

\section{Discussion}

The proportions of $\mathrm{CD}^{+}$or $\mathrm{CD}^{+} \mathrm{T}$ cells and $\mathrm{B} 220^{+} \mathrm{B}$ cells showed less reduction and/or faster recovery in lymph nodes than the spleen in this study. This might be because dendritic cells and macrophages which engulf and digest antigens migrate to lymph nodes and stimulate lymphocyte immigration and proliferation there $[1,7,16,26]$. According to a recent paper [3], $\mathrm{CD}^{+}$cell percentages in lymph nodes and the ratio of $\mathrm{FoxP}^{+}$cells among the $\mathrm{CD} 4^{+}$cells increased in the abdomen of the mouse after $\mathrm{x}$-irradiation compared to the controls. In our results, the ratio of Foxp $3^{+}$cells in lymph nodes increased following E-irradiation than the sham-irradiated controls. Thus, Treg cells might be more radioresistant than $\mathrm{CD}^{+}$cells. The other possibility is Treg migration and/or differentiation had increased to counteract excessive inflammation response caused by irradiation.

Statistically significant reduction was observed the proportion for $\mathrm{CD}_{11 \mathrm{~b}^{+}}$and $\mathrm{CD} 11 \mathrm{c}^{+}$spleen cells of the sham-irradiated mice. Even though the sham-irradiated mice are not irradiated, they were repeatedly anesthetized and taped down on the irradiation stage for six days just like the irradiated mice. The immune cell proportions in spleen of the sham-irradiated mice might have been affected by these stressful treatments.

As previously reported [36], cells of the thickened epidermis region were stained for K-14 after radiation in our study. Keratin is a filament forming protein of epithelial cells and helps to maintain tissue structure [27] as well as protects epithelial cells from stress [9]. When cells stratify and differentiate, K-14 and K-5 expression is down-regulated while $\mathrm{K}-1$ and $\mathrm{K}-10$ expression is up-regulated [6]. In other words, K-14 and K-5 are expressed in dividing basal keratinocytes of the skin epidermis [24].

We also observed increased expression of TGF- $\beta 1$ in epidermis after irradiation similar to what has been already known [18]. As TGF- $\beta 1$ induces differentiation of $\mathrm{FoxP3}^{+}$ Treg and Th17 cells $[11,35]$, we tested whether TGF- $\beta 1$ was co-stained with FoxP3 in the skin of the radiodermatitis model. Our data showed that TGF- $\beta 1$ and FoxP3 were expressed in different locations, while K-14 and IL-17 were co-stained with TGF- $\beta 1$ in the E-irradiated epidermis. Thus, it seems that TGF- $\beta 1$ is expressed mainly from keratinocytes in the basal layer $[4,21,32]$. $T$ cells which express receptors of TGF- $\beta 1[2,12]$ might have been recruited and stimulated by TGF- $\beta 1$, resulting in differentiation to Th17 cells $[4,35]$. However, this is only possibility as we did not check the expression of other Th17 cell markers such as IL-21 and IL-22. IL-17 produced by Th17 cells [11] and dendritic cells [10] might have bound to IL-17 receptors on the K-14 expressing keratinocytes [23,30]. Related to this, IL- 6 and IL-17 which play important roles in the formation of Th17 cells were simultaneously expressed in many cells of radiodermatitis lesions after 15 days of irradiation.

IL-10 is an essential cytokine for differentiation and function of Treg just like TGF- $\beta 1$, and is secreted from Treg [8]. We investigated if increased IL-10 is produced by Treg. IL-10 expression was increased substantially around hair follicles after irradiation just as reported previously [28]. Double staining showed that FoxP3 expression was scattered throughout the dermis region after irradiation, while IL-10 expression was concentrated in some areas of the dermis, suggesting that Treg is not the main source of IL-10. Dendritic cells and macrophages can also express IL-10 $[8,15,22,25]$. However, our results showed that increased ex- 
pression of IL-10 after irradiation did not occur in dendritic cells or macrophages, as most of the IL-10 positive cells are not co-stained with CD11b or CD11c. IL-10 receptor is known to be expressed on Th17 cells, and IL-10 suppresses Th17 cells [13]. In our results, IL-10 and IL-17 were rarely detected in the same cells even though the expression of both IL-10 and IL-17 were increased in the dermis of skin on the $15^{\text {th }}$ and $24^{\text {th }}$ day after E-irradiation. The type of cell which expresses most of IL-10 could not be determined in this study. As T regulatory 1 (Tr1) cellsexpress IL-10 [19,34], the increased expression of IL-10 in our mouse model could be from these cells.

We tried to find an irradiation protocol to induce rediodermatitis without affecting general health conditions of the mice. However, reproducible radiodermatitis mice model was not achieved using lower dose irradiation than what was used in this experiment. Body weights of the radiodermatitis model mice were decreased than the sham-irradiated mice after E-irradiation. Thus, we cannot rule out the possibility that the immunological changes we observed in this study were somewhat affected by the deteriorated health conditions of the mice.

Our results using radiodermatitis mouse model showed that TGF- $\beta 1$ is mainly produced by the thickened epidermal keratinocytes.

\section{Acknowledgement}

This work was supported by the Korea Science and Engineering Foundation (KOSEF) grant funded by the Korea government (MEST) (No. 2009-0067243).

\section{References}

1. Banchereau, J. and R. M. Steinman. 1998. Dendritic cells and the control of immunity. Nature 392, 245-252.

2. Bettelli, E., T. Korn, M. Oukka, and V. K. Kuchroo. 2008. Induction and effector functions of $\mathrm{T}(\mathrm{H}) 17$ cells. Nature 453, 1051-1057.

3. Billiard, F., V. Buard, M. Benderitter, and C. Linard. 2011. Abdominal gamma-radiation induces an accumulation of function-impaired regulatory $\mathrm{T}$ cells in the small intestine. Int. J. Radiat. Oncol. Biol. Phys. 80, 869-876.

4. Blanpain, C., W. E. Lowry, A. Geoghegan, L. Polak, and E. Fuchs. 2004. Self-renewal, multipotency, and the existence of two cell populations within an epithelial stem cell niche. Cell 118, 635-648.
5. Buschke, S., H. J. Stark, A. Cerezo, S. Pratzel-Wunder, K. Boehnke, J. Kollar, L. Langbein, C. H. Heldin, and P. Boukamp. 2011. A decisive function of transforming growth factor-beta/Smad signaling in tissue morphogenesis and differentiation of human HaCaT keratinocytes. Mol. Biol. Cell 22, 782-794.

6. Byrne, C., M. Tainsky, and E. Fuchs. 1994. Programming gene expression in developing epidermis. Development 120 , 2369-2383.

7. Cao, M., R. Cabrera, Y. Xu, C. Liu, and D. Nelson. 2011. Different radiosensitivity of $\mathrm{CD} 4(+) \mathrm{CD} 25(+)$ regulatory $\mathrm{T}$ cells and effector $\mathrm{T}$ cells to low dose gamma irradiation in vitro. Int. J. Radiat. Biol. 87, 71-80.

8. Chapoval, S., P. Dasgupta, N. J. Dorsey, and A. D. Keegan. 2010. Regulation of the T helper cell type 2 (Th2)/T regulatory cell (Treg) balance by IL-4 and STAT6. J. Leukoc. Biol. 87, 1011-1018.

9. Coulombe, P. A. and M. B. Omary. 2002. 'Hard' and 'soft' principles defining the structure, function and regulation of keratin intermediate filaments. Curr. Opin. Cell Biol. 14, 110-122.

10. Cua, D. J. and C. M. Tato. 2010. Innate IL-17-producing cells: the sentinels of the immune system. Nat. Rev. Immund. 10, 479-489.

11. Dong, C. 2008. TH17 cells in development: an updated view of their molecular identity and genetic programming. Nat. Rev. Immunol. 8, 337-348.

12. Hirahara, K., K. Ghoreschi, A. Laurence, X. P. Yang, Y. Kanno, and J. J. O'Shea. 2010. Signal transduction pathways and transcriptional regulation in Th17 cell differentiation. Cytokine Growth Factor Rev. 21, 425-434.

13. Huber, S., N. Gagliani, E. Esplugues, W. O'Connor, Jr., F. J. Huber, A. Chaudhry, M. Kamanaka, Y. Kobayashi, C. J. Booth, A. Y. Rudensky, M. G. Roncarolo, M. Battaglia, and R. A. Flavell. 2011. Th17 Cells Express Interleukin-10 Receptor and Are Controlled by Foxp3(-) and Foxp3(+) Regulatory CD4(+) T Cells in an Interleukin-10-Dependent Manner. Immunity 34, 554-565.

14. Ito, Y., P. Sarkar, Q. Mi, N. Wu, P. Bringas, Jr., Y. Liu, S. Reddy, R. Maxson, C. Deng, and Y. Chai. 2001. Overexpression of Smad2 reveals its concerted action with Smad4 in regulating TGF-beta-mediated epidermal homeostasis. Dev. Biol. 236, 181-194.

15. Liu, C., J. Lin, L. Zhao, Y. Yang, F. Gao, B. Li, J. Cui, and J. Cai. 2011. Gamma-ray Irradiation Impairs Dendritic Cell Migration to CCL19 by Down-regulation of CCR7 and Induction of Cell Apoptosis. Int. J. Biol. Sci. 7, 168-179.

16. Lorimore, S. A., P. J. Coates, G. E. Scobie, G. Milne, and E. G. Wright. 2001. Inflammatory-type responses after exposure to ionizing radiation in vivo: a mechanism for radiation-induced bystander effects?. Oncogene 20, 7085-7095.

17. Maeng, H. G., D. N. Kim, S. K. Cho, J. H. Cha, T. Y. Kim, Y. S. Lee, D. K. Choi, J. H. Lee, M. J. Cho, H. J. Kwon, and S. K. Lee. 2006. Altered immune cell proportions in the radiodermatitis induced hairless mice-1 (HR-1). J. Radiat. 
Res. (Tokyo) 47, 9-17.

18. Martin, M., J. Lefaix, and S. Delanian. 2000. TGF-beta1 and radiation fibrosis: a master switch and a specific therapeutic target?. Int. J. Radiat. Oncol. Biol. Phys. 47, 277-290.

19. Mills, K. H. 2004. Regulatory T cells: friend or foe in immunity to infection?. Nat. Rev. Immunol. 4, 841-855.

20. Miossec, P., T. Korn, and V. K. Kuchroo. 2009. Interleukin-17 and type 17 helper T cells. N. Engl. J. Med 361, 888-898.

21. Morris, R. J., Y. Liu, L. Marles, Z. Yang, C. Trempus, S. Li, J. S. Lin, J. A. Sawicki, and G. Cotsarelis. 2004. Capturing and profiling adult hair follicle stem cells. Nat. Biotechnol. 22, 411-417.

22. Murai, M., O. Turovskaya, G. Kim, R. Madan, C. L. Karp, H. Cheroutre, and M. Kronenberg. 2009. Interleukin 10 acts on regulatory $\mathrm{T}$ cells to maintain expression of the transcription factor Foxp3 and suppressive function in mice with colitis. Nat. Immunol. 10, 1178-1184.

23. Nakajima, K., T. Kanda, M. Takaishi, T. Shiga, K. Miyoshi, H. Nakajima, R. Kamijima, M. Tarutani, J. M. Benson, M. M. Elloso, L. L. Gutshall, M. F. Naso, Y. Iwakura, J. DiGiovanni, and S. Sano. 2011. Distinct roles of IL-23 and IL-17 in the development of psoriasis-like lesions in a mouse model. J. Immunol. 186, 4481-4489.

24. Romano, R. A., B. Birkaya, and S. Sinha. 2007. A functional enhancer of keratin14 is a direct transcriptional target of deltaNp63. J. Invest. Dermatol. 127, 1175-1186.

25. Said, E. A., F. P. Dupuy, L. Trautmann, Y. Zhang, Y. Shi, M. El-Far, B. J. Hill, A. Noto, P. Ancuta, Y. Peretz, S. G. Fonseca, J. Van Grevenynghe, M. R. Boulassel, J. Bruneau, N. H. Shoukry, J. P. Routy, D. C. Douek, E. K. Haddad, and R. P. Sekaly. 2010. Programmed death-1-induced interleukin-10 production by monocytes impairs CD4+ T cell activation during HIV infection. Nat. Med 16, 452-459.

26. Sauter, B., M. L. Albert, L. Francisco, M. Larsson, S. Somersan, and N. Bhardwaj. 2000. Consequences of cell death: exposure to necrotic tumor cells, but not primary tissue cells or apoptotic cells, induces the maturation of im- munostimulatory dendritic cells. J. Exp. Med 191, 423-434.

27. Schweizer, J., P. E. Bowden, P. A. Coulombe, L. Langbein, E. B. Lane, T. M. Magin, L. Maltais, M. B. Omary, D. A. Parry, M. A. Rogers, and M. W. Wright. 2006. New consensus nomenclature for mammalian keratins. J. Cell. Biol. 174, 169-174.

28. Shen, J., S. Bao, and V. E. Reeve. 1999. Modulation of IL-10, IL-12, and IFN-gamma in the epidermis of hairless mice by UVA (320-400 nm) and UVB $(280-320 \mathrm{~nm})$ radiation. J. Invest. Dermatol. 113, 1059-1064.

29. Shevach, E. M. 2009. Mechanisms of foxp $3+$ T regulatory cell-mediated suppression. Immunity 30, 636-645.

30. Tokura, Y., T. Mori, and R. Hino. 2010. Psoriasis and other Th17-mediated skin diseases. J. UOEH. 32, 317-328.

31. Tucker, R. F., G. D. Shipley, H. L. Moses, and R. W. Holley. 1984. Growth inhibitor from BSC-1 cells closely related to platelet type beta transforming growth factor. Science 226, 705-707.

32. Tumbar, T., G. Guasch, V. Greco, C. Blanpain, W. E. Lowry, M. Rendl, and E. Fuchs. 2004. Defining the epithelial stem cell niche in skin. Science 303, 359-363.

33. Wang, X. J., D. A. Greenhalgh, J. R. Bickenbach, A. Jiang, D. S. Bundman, T. Krieg, R. Derynck, and D. R. Roop. 1997. Expression of a dominant-negative type II transforming growth factor beta (TGF-beta) receptor in the epidermis of transgenic mice blocks TGF-beta-mediated growth inhibition. Proc. Natl. Acad Sci. USA 94, 2386-2391.

34. Weiss, E., A. J. Mamelak, S. La Morgia, B. Wang, C. Feliciani, A. Tulli, and D. N. Sauder. 2004. The role of interleukin 10 in the pathogenesis and potential treatment of skin diseases. J. Am Acad Dermatol. 50, 657-675; quiz 676-658.

35. Wing, K., Z. Fehervari, and S. Sakaguchi. 2006. Emerging possibilities in the development and function of regulatory T cells. Int. Immunol. 18, 991-1000.

36. Yang, L., L. Wang, and X. Yang. 2009. Disruption of Smad4 in mouse epidermis leads to depletion of follicle stem cells. Mol. Biol. Cell 20, 882-890. 
초록 : E-ray를 조사한 쥐의 피부에서 증식된 keratinocyte에 의한 TGF- $\beta 1$ 발현

윤아란 ${ }^{1} \cdot$ 김도년 $^{1} \cdot$ 서민구 ${ }^{1} \cdot$ 오상택 $^{1} \cdot$ 서정선 ${ }^{1} \cdot$ 전세모 $^{1} \cdot$ 차정호 $^{2} \cdot$ 이승덕 ${ }^{3} \cdot$ 이숙경 ${ }^{1} \star$

( ${ }^{1}$ 가톨릭대학교 의과대학 의생명과학교실 면역생물학연구소, ${ }^{2}$ 가톨릭대학교 의과대학 해부학교실, ${ }^{3}$ 동국대 학교 한의예과)

우리는 방사선피부염 동물 모델을 확립하여, 이차 면역 기관에서의 면역 세포 비율 변화를 관찰하였다. 또한, 방사선 조사에 의한 병소에서 transforming growth factor- $\beta 1$ (TGF- $\beta 1$ )과 interlukin-10 (IL-10)의 발현을 증가시 킨 세포를 분석하였다. Hairless-1 (HR-1) 쥐의 posterior dorsal 부위에 6 일간 매일 $10 \mathrm{~Gy}$ 씩 electron (E)-ray를 국부 조사하여 방사선피부염 모델을 만들었다. FACS를 이용하여 면역 세포 비율의 변화를 분석한 결과 비장과 림프절에 존재하는 항원제시세포와 $\mathrm{T}$ 세포 및 $\mathrm{B}$ 세포들의 비율이 E-irradiation에 의해 영향을 받았다. 피부에서 세포 특이적인 마커와 사이토카인들의 발현 양상은 면역형광염색법으로 확인하였다. 방사선 조사 후, TGF- $\beta 1$ 과 interlukin-17 (IL-17)은 regulatory T 세포(Treg)보다 keratin-14 (K-14)를 발현하는 진피의 끝부분에서 높게 발현 되었다. Interlukin-10 (IL-10)는 Treg 뿐만 아니라 T helper 17 (Th17) 세포, dendritic 세포, macrophage 중 어느 것과도 같은 위치에서 검출되지 않았다. 우리의 데이터는 방사선피부염 동물 모델의 병소 안에서, TGF- $\beta 1$ 이 증 식된 keratinocyte에 과발현된다는 것을 나타낸다. 